\title{
MICROSCOPIC, PHYSICOCHEMICAL AND PHYTOCHEMICAL ANALYSIS OF GARDENIA JASMINOIDES (ELLIS)
}

\author{
KEERTHANA KESAVAN', JOTHI GNANASEKARAN², SRIDHARAN GURUNAGARAJAN³, AGNEL ARUL JOHN \\ NAYAGAM ${ }^{4}$
}

1Department of Biochemistry, Srimad Andavan Arts and Science College (Autonomous), No. 7, Nelson Road, Thiruvanaikovil, Tiruchirappalli 620005. Tamil Nadu, India, ${ }^{2}$ Dean Sciences, Srimad Andavan Arts and Science College (Autonomous), No.7, Nelson Road, Thiruvanaikovil, Tiruchirappalli 620005 Tamil Nadu, India, ${ }^{3}$ Department of Biochemistry, Srimad Andavan Arts and Science College (Autonomous), No.7, Nelson Road, Thiruvanaikovil, Tiruchirappalli 620005. Tamil Nadu, India, ${ }^{4}$ Department of Biochemistry, Srimad Andavan Arts and Science College (Autonomous), No.7, Nelson Road, Thiruvanaikovil, Tiruchirappalli 620005 Tamil Nadu, India Email: keerthuk7@gmail.com

Received: 27 Jul 2017 Revised and Accepted: 22 Nov 2017

\section{ABSTARCT}

Objective: To evaluate the microscopical, physicochemical and phytochemical analysis of Gardenia jasminoides (Ellis).

Methods: The leaves of Gardenia jasminoides (Ellis) was studied through macroscopic, microscopic, physicochemical standards such as moisture content, ash values, extractive values and phytochemical analysis includes preliminary screening and quantification of important secondary metabolites were carried out as per the standard procedures are given in Indian Ayurvedic Pharmacopeia.

Results: Microscopic studies of leaf showed the presence of epidermis, 4-5 layers of collenchymas cells, xylem, phloem and vascular bundles. The determination of physicochemical studies of leaves showed that it contains Total ash (6.98\%), Water and Acid insoluble ash values and extractive values of $0.31 \%$ in Hexane, $0.87 \%$ in chloroform and $0.42 \%$ in Ethyl acetate. Preliminary phytochemical screening revealed the presence of Alkaloid, Flavonoid, Saponin, Tannin and phenol.

Conclusion: The results obtained from the study provide information for proper identification and standardization of plant for its medicinal property, ensuring the quality of plant drug and also useful to distinguish it from its related species.

Keywords: Gardenia jasminoides, Microscopic, Physicochemical, Phytochemical

(C) 2018 The Authors. Published by Innovare Academic Sciences Pvt Ltd. This is an open-access article under the CC BY license (http://creativecommons.org/licenses/by/4.0/) DOI: http://dx.doi.org/10.22159/ijpps.2018v10i1.21665

\section{INTRODUCTION}

Plants are used to treat various ailments from immemorial period. Plants have been used medicinally for thousands of years by various cultures all over the world. From the WHO data, it reveals that the $80 \%$ of the world's population uses plant-based remedies as their primary health care [1]. In most of the countries, herbal medicines are still a central part of the medical system, such as Ayurvedic medicine in India and traditional Chinese medicine in China [2].

Nowadays the herbal medicine is gaining more attention all over the world due to the long historical practice and less side effects. The rise in the use of herbal product paves the way for different forms of abuse and adulteration. Standardization of the medicinal plants will ensure that the plants are conserved for their medicinal and nutritive value. Standardization confirms the safety of the medicinal plants [3]. The Standardization of drug means confirmation of its identity, quality and purity throughout all phases of its cycle. The standardization of a plant drug involves the following study that includes microscopic, macroscopic, physicochemical and phytochemical characteristics of the selected plant.

Gardenia jasminoides (Ellis) belongs to the family Rubiaceae, it is widely present as a garden plant in warm temperate and subtropical gardens and used for the treatment of pain, nosebleeds, fever, influenza, healing wounds, reducing swelling, mastitis, hepatitis and hematuria in Indian system of medicine. Gardenia jasminoides fructus (fruit) is used within Traditional Chinese Medicine to "drain fire" and thereby treat certain febrile conditions [4].

Hence the present was made to carry out the pharmacognostical and preliminary phytochemical evaluation of the leaf of Gardenia jasminoides as per the procedures mentioned in Ayurvedic Pharmacopeia.

\section{MATERIALS AND METHODS}

\section{Plant material}

The leaves of the selected plants were collected in Srirangam, Trichy and authenticated with the Voucher No-KK01 in the herbarium specimen deposited at RAPINAT herbarium of St. Joseph's College, Trichy, Tamilnadu, India. Then the collected leaves were shade dried, powdered using a mixer and used for further analysis.

\section{Botanical standards}

\section{Powder microscopy}

The dried powdered leaves were treated with various chemicals and studied under a microscope using various chemical treatments. A pinch of powder was taken in a microscopic slide, 1-2 drops of $0.1 \% \mathrm{w} / \mathrm{v}$ phloroglucinal solution and a drop of concentrated hydrochloric acid were added and covered with a coverslip.

The slide preparation was mounted in glycerol and examined under a microscope. The presence of starch grain and calcium oxalate crystal was detected by the formation of blue colour on addition of 2-3 drops of $0.01 \mathrm{M}$ iodine solution [5]. The characteristics features of cell components were observed and their photographs were taken using photomicrography.

\section{Microscopic analysis}

Transverse section of midrib, petiole and lamina of fresh leaf were cut by using potato pith method. The sections were cleared by boiling with chloral hydrate solution and stained with a mixture of phloroglucinol and hydrochloric acid (1:1), and studied under a compound microscope (10 X and $45 \mathrm{X})$. 


\section{Physico-chemical evaluation}

Physico-chemical parameters such as the percentage of loss on drying (LOD), Total ash, Acid insoluble ash, Water soluble ash were determined as per the Indian Pharmacopoeia. [6] Water and alcohol soluble extractive were estimated by cold maceration according to the method prescribed by WHO [7]. All the parameters were taken in triplicate and the result which was obtained presented as mean \pm standard error of the mean (SEM).

\section{Preliminary phytochemical screening}

The plant powder and various extracts of Gardenia jasminoides were subjected to qualitative phytochemical analysis [8].

\section{Quantitative phytochemical analysis}

The estimation of important secondary metabolites such as Alkaloids [9], Flavonoids [10] and Total Phenol content [11] and Tannins [12] was studied using standard textual procedures.

\section{Statistical analysis}

All the experiments were done in triplicates. The experimental results are expressed as mean $\pm \mathrm{SD}$ where $n=3$.

\section{RESULTS AND DISCUSSION}

\section{Botanical standards}

\section{Microscopic analysis}

The transverse section of Gardenia jasminoides midrib (fig. 1a, 1b) reveals that the midrib of leaf showed the presence of upper and lower epidermis, collenchymas, cortex and vascular bundle. Upper epidermal cells are larger than the lower epidermal cells and both are globular in shape with thick cuticle (fig. 1a, 1b). Collenchyma cells are found in 4-5 layers below the epidermis. Cortex consists of several layered parenchyma cells with the globular and ovoid shape.

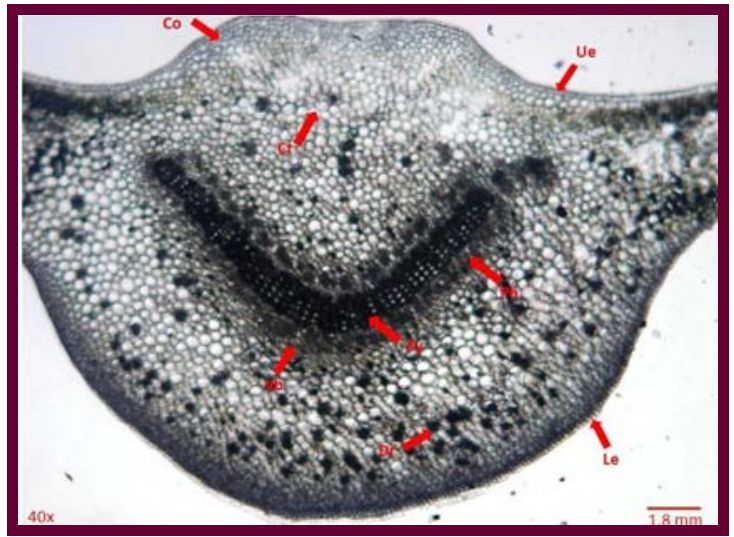

Fig. 1a: T. S. of Gardenia jasminoides (Ellis). Leaf midrib

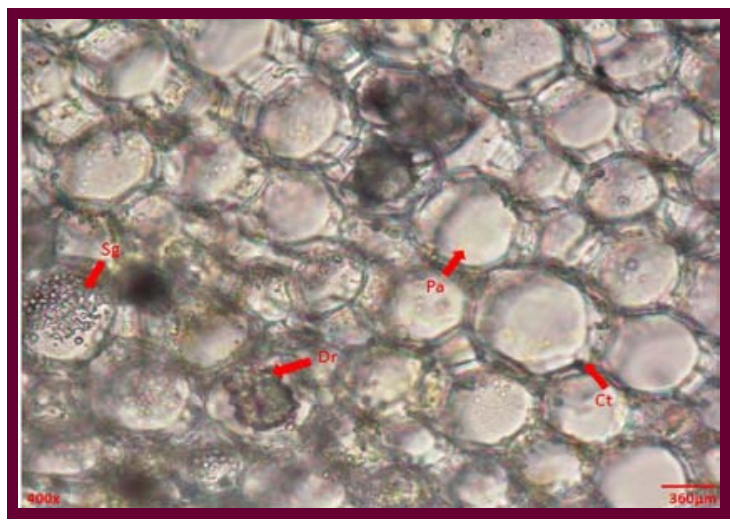

Fig. 1b: T. S. of Gardenia jasminoides (Ellis). Leaf midrib (enlarged view)

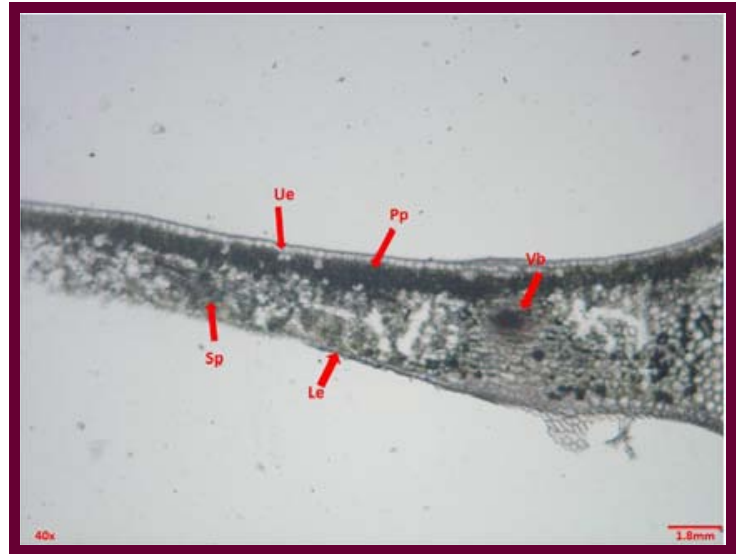

Fig. 2a: T. S. of Gardenia jasminoides (Ellis). Leaf lamina

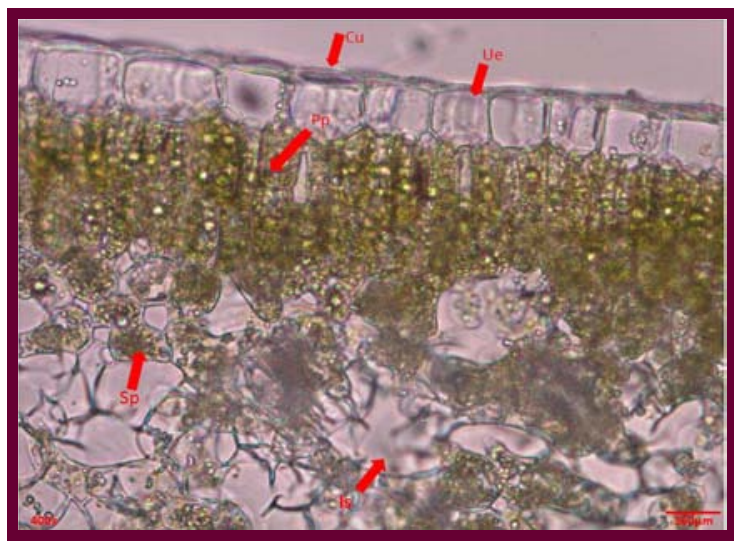

Fig. 2b: T. S. of Gardenia jasminoides (Ellis). Leaf lamina (enlarged view)

Some idioplast cells and cortical fibres are found in the cortex. The cortex contains druses type of calcium oxalate crystals and starch grains with the oval and globular shape. The Vascular bundle is crescent shaped. Phloem consists of 3-4 layered cells. Xylem elements are arranged in several rows. Cambium is not distinct. Two small vascular bundles are found near to the main vascular bundle.

The transverse section of the lamina (fig. 2a, 2b) contains upper and lower epidermis with rectangular shaped cells. Upper epidermal cells are larger than the lower epidermal cells. In some places, the epidermal cells are arranged in two rows. Both upper and lower epidermis contain thick cuticle. The outer wall of upper epidermis shows projections. Palisade cells are found as both shorter and elongated structures. Spongy parenchyma is several layered with large intercellular spaces.

Along with spongy parenchyma, some of the large globular parenchyma cells are present without chloroplast. Idioplast cells and druses type of calcium crystals are found in the spongy parenchyma. Bundle sheaths and vascular bundles are found. Globular starch grains are present in some of the epidermal cells and spongy parenchyma [13].

\section{Powder microscopy}

Powder microscopy studies of Gardenia jasmonoides leaf shows the presence of characteristic feature such as unicellular, uniseriate trichomes, druses, prismatic and acicular calcium oxalate crystals. The parenchyma cells containing brown content, aseptate and septate fibres with the wide lumen, the starch grains were simple, compound, round, ovoid, polygonal and irregular shape with striated margins and xylem vessels present with spiral thickening. These entire features showed in the fig. 3a-k. 


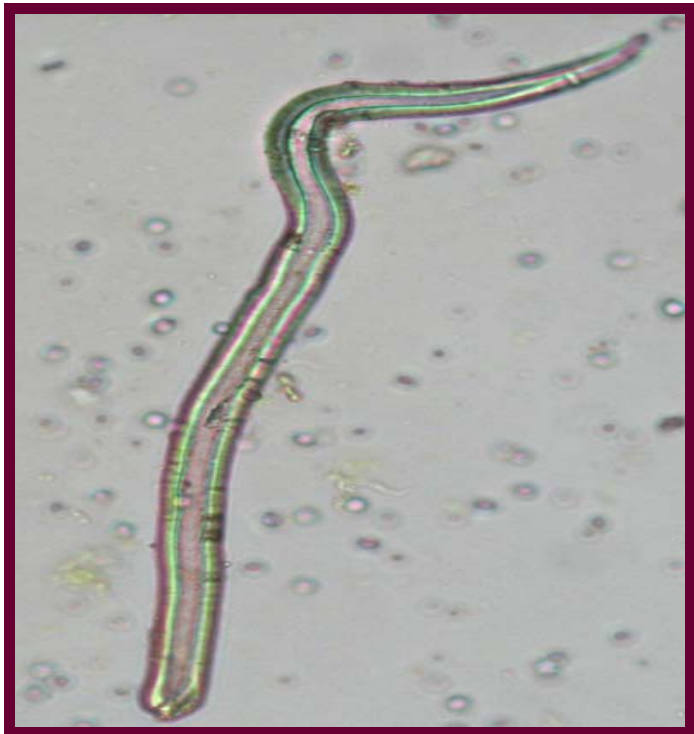

Fig. 3a: Unicellular trichome

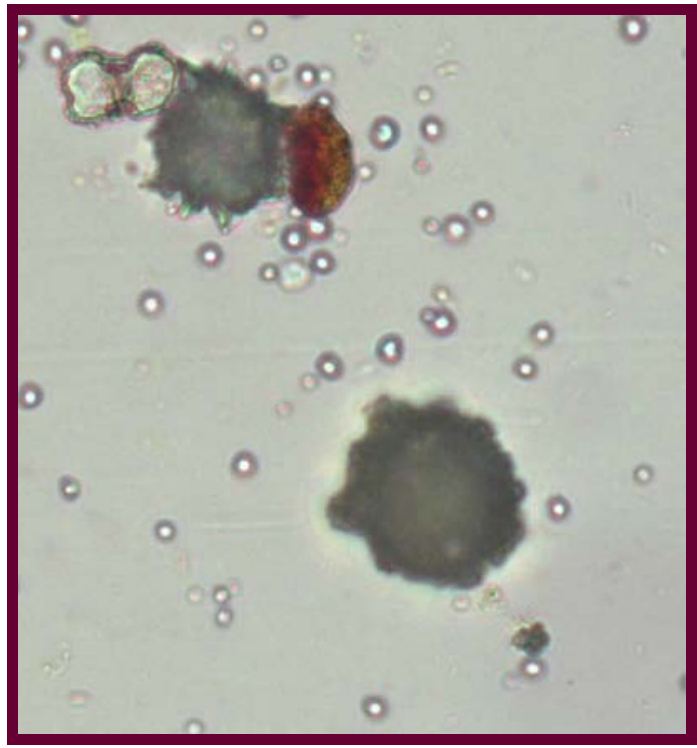

Fig. 3c: Druses calcium oxalate crystals (400x)

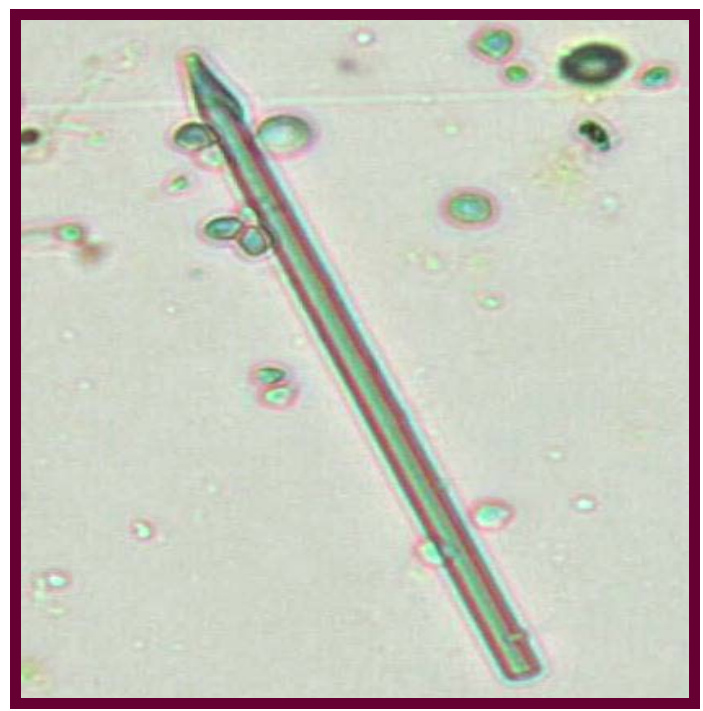

Fig. 3e: Acicular calcium oxalate crystals (400x)

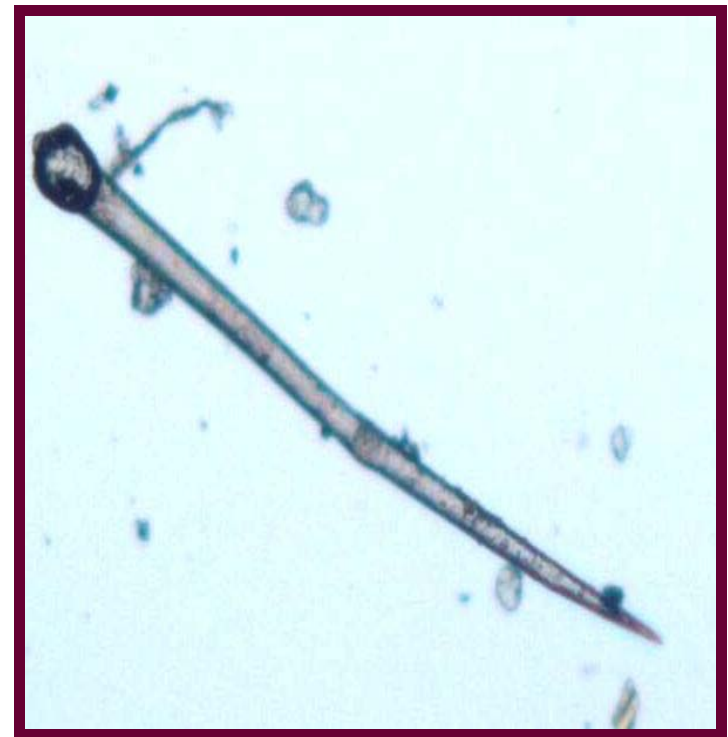

Fig. 3b: Uniseriate trichome (200x)

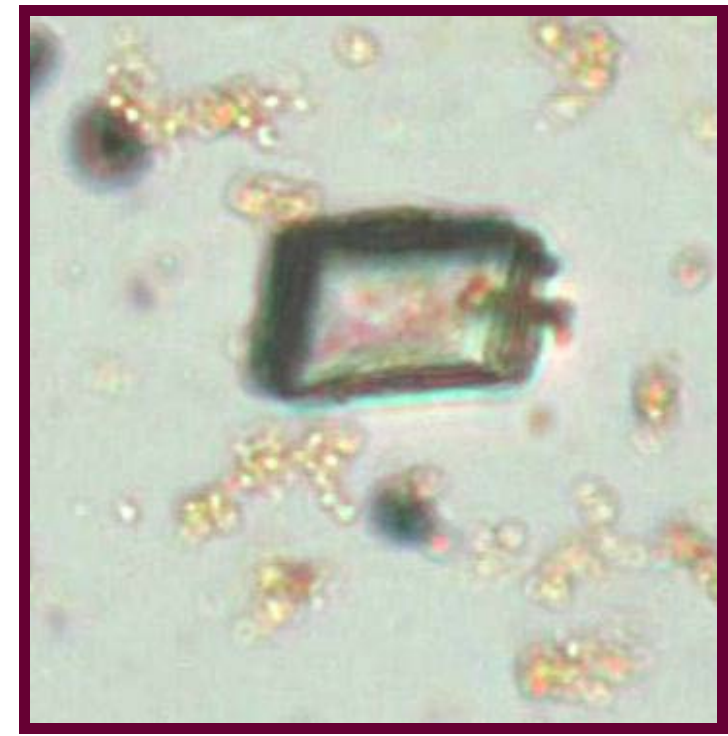

Fig. 3d: Prismatic calcium oxalate crystals (400x)

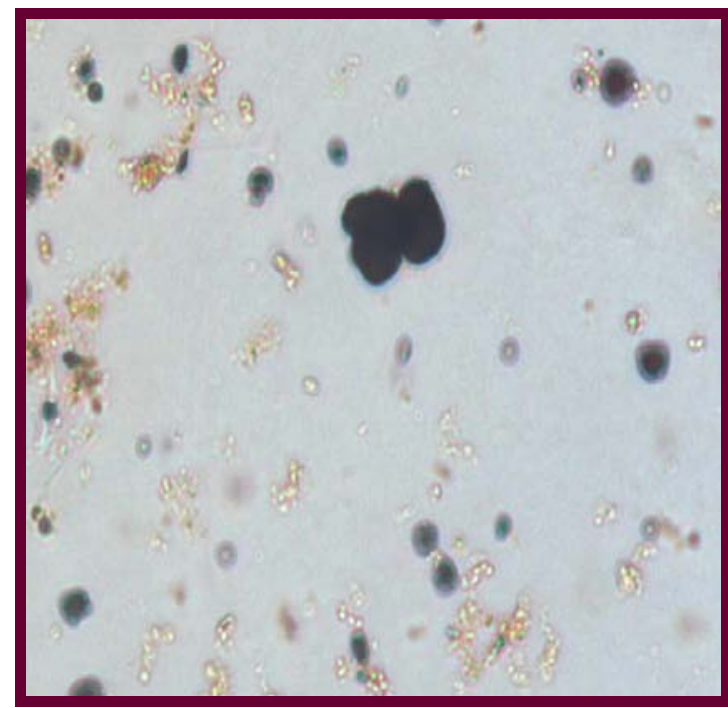

Fig. 3f: Starch grains $(400 x)$ 


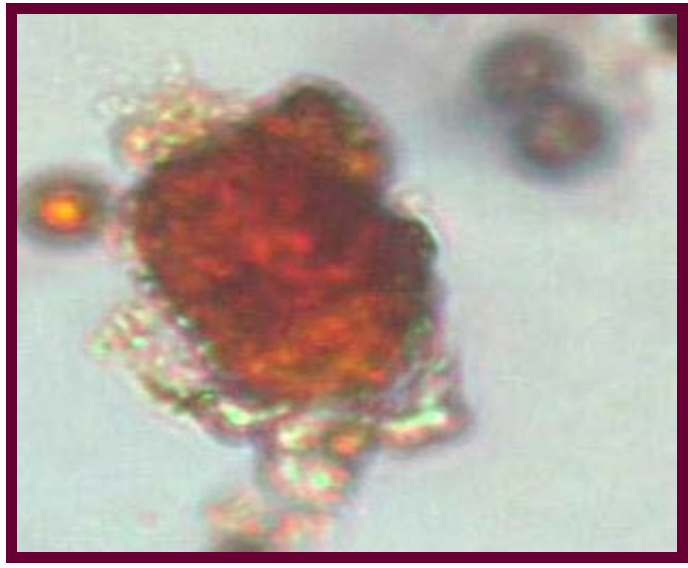

Fig. 3g: Acicular calcium oxalate crystals (400x)

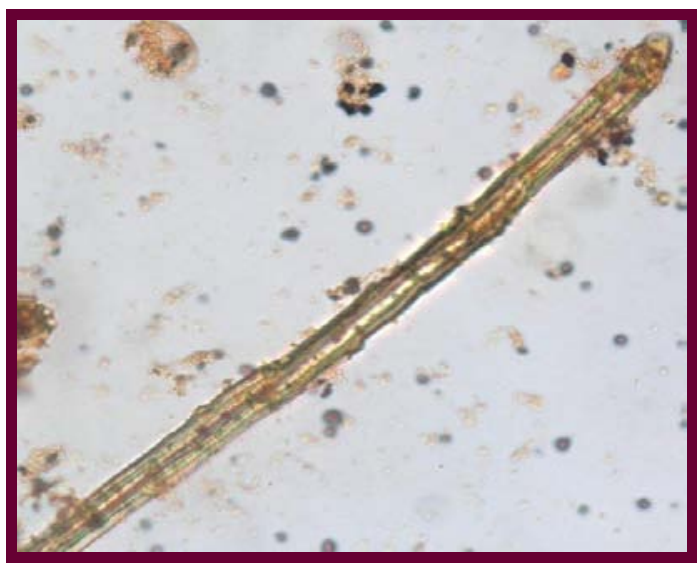

Fig. 3i: Aseptate fibre (400x)

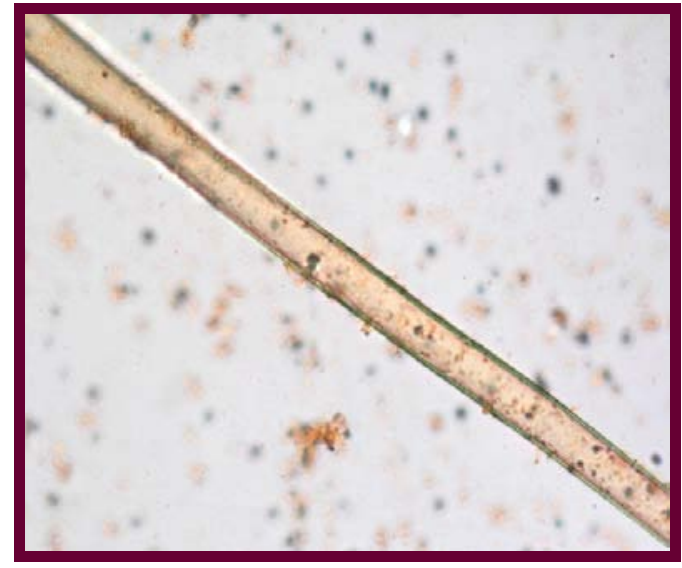

Fig. 3h: Aseptate fibre (400x)

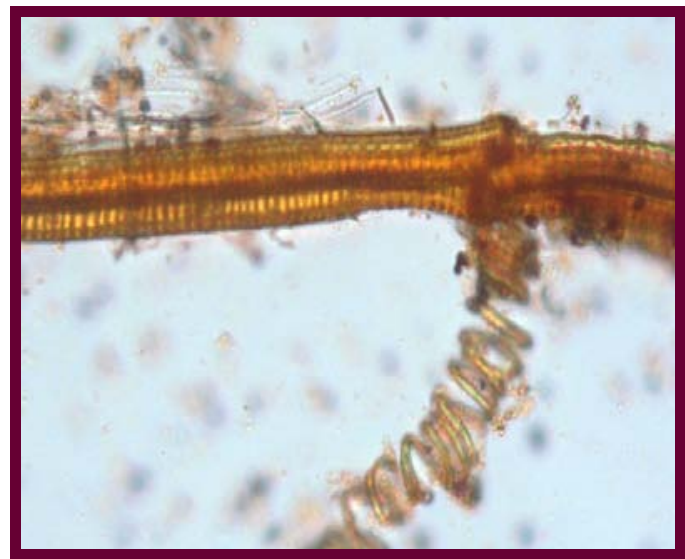

Fig. 3j: Xylem vessels with spiral thickening (400x)

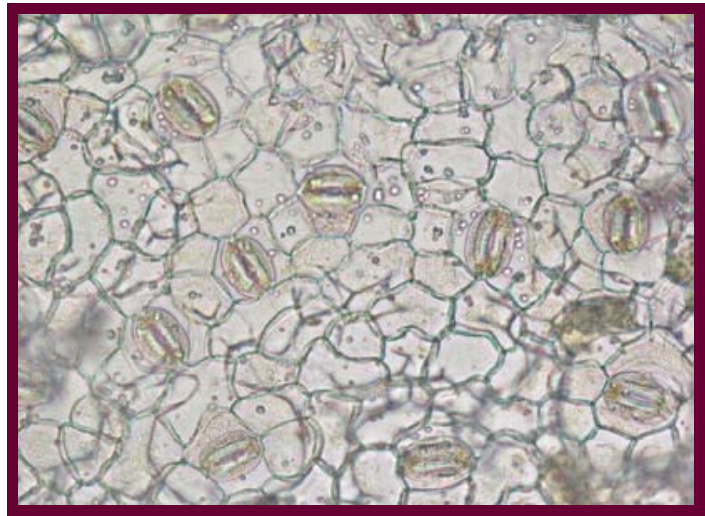

Fig. 3k: Leaf epidermis with stomata (400x)

Physicochemical constants

Table 1: Physico chemical analysis of Gardenia jasminoides

\begin{tabular}{llc}
\hline S. No. & Physicochemical parameters & Values \%(w/w) \\
\hline 1. & Foreign matter & $1.80 \pm 0.12$ \\
2. & Moisture content & $3.58 \pm 0.15$ \\
3. & Total Ash & $6.16 \pm 0.31$ \\
4. & Water-soluble Ash & $3.81 \pm 0.37$ \\
5. & Acid-insoluble Ash & $0.77 \pm 0.07$ \\
& Extractive values & $0.34 \pm 0.03$ \\
7. & Hexane soluble extract & $0.82 \pm 0.02$ \\
8. & Chloroform soluble extract & $0.43 \pm 0.03$ \\
9. & Ethyl acetate soluble extract & \\
10. & Solubility Values & $9.70 \pm 0.16$ \\
\end{tabular}

Values are mean \pm SEM $(n=3)$ 
The results of physicochemical characteristics of the selected plant material were shown in the table 1 . The constituents other than plant material are considered to be the foreign matter and the collected plants should be entirely free from soil, stones, insects and other contaminants. The presence of a decreased level of foreign matter indicates the purity of the collected plant materials of the selected plant. The Total ash content of Gardenia jasminoides was found to be $6.98 \%$. The decreased value in acid insoluble ash indicates the purity of the plant drugs. The high total ash relative with decreased acid insoluble ash indicates the presence of higher amount of inorganic compounds. The determination of extractable matters refers to the amount of constituents in a given amount of medicinal plant material extracted with solvents. Such extractive values provide an indication of the extent of polar, medium polar and non-polar components present in the medicinal plant material [14]. From the data obtained it was found that the water solubility was found to be higher when comparing to ethanol solubility.

Table 2: Preliminary phytochemical screening of Gardenia jasminoides Ellis

\begin{tabular}{lllll}
\hline S. No. & Test for & Drug powder & Ethanol & Aqueous extract \\
\hline 1 & Saponin & + & + & + \\
+ \\
2 & Tannin & - & - & - \\
3 & Sterol & - & - & - \\
4 & Terpene & + & + & + \\
5 & Flavanoid & - & - & - \\
6 & Coumarin & - & - & - \\
7 & Quinone & - & + & - \\
8 & Lignin & - & + & - \\
9 & Alkaloid & - & - & - \\
10 & Glycosides & - & + & + \\
12 & Sugar & + & & \\
\end{tabular}

Note: (-) Absence, (+) Presence

The results of the phytochemical analysis showed in the table 2 revealed that the ethanol extract of Gardenia jasminoides Ellis. possess saponin, tannin, flavonoid, alkaloid, glycosides and phenols. The drug powder and aqueous extract showed the presence of saponin, tannin, flavonoid and phenols.

The importance of polyphenolic compounds such as flavonoid, saponin, tannin present in the extracts was well documented for their antimicrobial activity against various pathogenic strains present in the wound. These phytochemicals present in the extracts may facilitate the extracts to act as wound healing substance [15]. Phytochemicals are plant chemicals known to play an important role in the biological activity of medicinal plants [19].

\section{Quantification of secondary metabolites}

Quantitative estimation of important secondary metabolites tabulated in the table 3 .
The alkaloid content of Gardenia jasminoides was found to be higher $2.81 \pm 0.31$ followed by flavonoid $2.77 \pm 0.20$. The amount of phenol was found to be $1.91 \pm 0.24$ and the tannins were $1.64 \pm 0.13$.

The process of wound healing is promoted by several herbal extracts, which are composed of active agents like triterpenes, alkaloids, flavonoids, tannins, saponins, anthraquinones, and other biomolecules [16]. Flavonoids are secondary metabolites widely distributed in plants they are a group of polyphenolic compounds with known properties, which include free radical scavenging inhibition of hydrolytic and oxidative enzymes and antiinflammatory action. A number of reports have shown that the presence of phenolics in foods is particularly important for their oxidative stability and antimicrobial protection [17]. Tannins are widely distributed in almost all plant foods. The tannin containing remedies are used as antihelminthic, antioxidants, antimicrobial agents and anti-viral agents [18].

Table 3: Quantitative analysis of secondary metabolites

\begin{tabular}{lll}
\hline S. No. & Parameters & Values \\
\hline 1. & Alkaloids & $2.81 \pm 0.31(\mathrm{mg} / \mathrm{g})$ \\
2. & Flavonoids & $2.77 \pm 0.20(\mathrm{mg} / \mathrm{g})$ Gallic Acid equivalent \\
3. & Total Phenol & $1.91 \pm 0.24(\mathrm{mg} / \mathrm{g})$ Gallic Acid equivalent \\
4. & Tannins & $1.64 \pm 0.13(\mathrm{mg} / \mathrm{g})$ \\
\hline
\end{tabular}

Values are mean $\pm \mathrm{SD}$ where $\mathrm{n}=3$

\section{CONCLUSION}

The present work was aimed to investigate the microscopical, physicochemical and phytochemical studies of Gardenia jasminoides (Ellis). The morphological features will helps to differentiate it from other related species. The physicochemical standards determined in the present study helps to check the quality of the raw material. The preliminary phytochemical screening and quantitative estimation of major secondary metabolites serves the important information about the phytoconstituents present in the plant material. From the results obtained, it was clear that the phytochemicals present in the plant have potential therapeutic or physiological actions on the human system.

\section{ACKNOWLEDGEMENT}

The authors greatly thanks to University Grant Commission, New Delhi for providing financial assistance to carry out this research work under Minor Research Project. [NO F MRP-5189/14 (MRP/UGC-SERO)]

\section{AUTHORS CONTRIBUTION}

We declare that all of the authors mentioned in the article have contributed equal efforts in this research and also for the submission of the article.

\section{CONFLICT OF INTERESTS}

The authors declare that there are no conflict of interest

\section{REFERENCES}

1. Evans WC. Trease and Evans' Pharmacognosy. 15 $5^{\text {th }}$ edn London: WB Saunders; 2001.

2. Barnes J, Anderson LA, Phillipson JD. Herbal medicine. $3^{\text {rd }}$ Edition. Pharmaceutical Press: London; 2007. p. 1-23. 
3. Nilakshi Pradhan, Jyoti Gavali, Nitin Waghmare. WHO (world health organization) guidelines for standardization of herbal drugs. International Ayurvedic Medical Journal; 2015.

4. Molony, David, Ming Ming Pan Molony. The American Association of Oriental Medicine's Complete Guide to Chinese Herbal Medicine. New York: Berkley Publishing; 1999.

5. Thitikornpong $\mathrm{W}$, Phadungcharoen $\mathrm{T}$, Sukrong $\mathrm{S}$. Pharmacognostic evaluations of Lagerstroemia speciosa leaves. J Med Plant Res 2011;5:1330-7.

6. Anonymous. Indian Ayurvedic Pharmacopoeia. Vol. II. Controller of Publications. Edition $4^{\text {th }}$ New Delhi: Government of India; 1996.

7. Anonymous. Quality Control Methods for Medicinal Plant Materials (An authorized publication of World Health Organization, Geneva). New Delhi: A. I. T. B. S. Publishers and Distributors (Regd.); 2002.

8. Brindha P, Sasikala, Bhima Rao. Pharmacognostic studies on Coleus Aromaticus. Benth. Indian Borage, B. M. E. B. R, Vol XII; 1991. p. 17-31.

9. Ferguson NM. A textbook of pharmacognosy, Mcmillan Company, New Delhi; 1956. p. 191.

10. Kadifkovapanovska T, Kulevanova S, Marina Stefova. In vitro antioxidant activity of some Teucrium species (Lamiaceae). Acta Pharm 2005;55:207-14.

11. Malick CP, Singh MB. Estimation of Phenol. In: Plant Enzymology and histoenzymology. New Delhi. Kalyani Publishers; 1980. p. 286.
12. The Ayurvedic Pharmacopoeia of India. Part II. (Formulations) Vol. II First Edition. The government of India, Ministry of Health and Family Welfare, AYUSH, New Delhi; 2008.

13. Pandita Nancy, Vaidya Ashlesha. Pharmacognostic and phytochemical studies of Cassia absus seed extracts. Int J Pharm Pharm Sci 2016;8:325-32.

14. Pravin Chandra PC. Medicinal Plants: Traditional Knowledge, IK International private limited; 2006. p. 1-8.

15. Kubmarawa D, Ajoku GA, Enworem NM, Okorie DA. Preliminary phytochemical and antimicrobial screening of 50 medicinal plants from Nigeria. Afr J Biotechnol 2007;6:1690-6.

16. Chaudhari M, Mengi S. Evaluation of phytoconstituents of Terminalia arjuna for wound healing activity in rats. Phytother Res 2006;20:799-805.

17. Carbanaro M, Mattera M, Nicoli S, Bergamo P, Cappelloni M. Modulattion of antioxidant compounds in organic vs conventional fruit (peach, Prunus persica and pear, Pyrus communis L.). J Agric Food Chem 2002;50:5458-62.

18. Koleckar V, Kubikova K, Rehakova Z, Kuca K, Jun D, Jahodar L. Condensed and hydrolysable tannins as antioxidants influencing the health. Mini Rev Med Chem 2008;8:436-77.

19. Jyoti Vandana, Gupta AK, Alok Mukerjee. Phytochemical screening and evaluation of anti-inflammatory activity of aerial parts extracts of plantago major L. Asian J Pharm Clin Res 2017;10:307-11. 